\title{
MODEL OF INTEGRATED TEACHING MARITIME ENGLISH IN DISTANT LEARNING MODE FOR NAVIGATORS
}

\author{
Ivasiuk N. A.
}

\section{INTRODUCTION}

The goals of our teaching in distant learning mode (synchronous and asynchronous) are the following:

- the process of implementing the latest modern IT in English language (EL) teaching process;

- the process of adapting the cadets or present seafarers to the creative approach in learning process, responsible attitude to their self-studies;

- affording the possibility of choosing the individual cadets' curriculum of studies, etc.

Our aim in distant mode of learning - learning progression - from experimental to expository.

In our scientific investigation, we keep to the idea of creating integrated information environment of virtual simulation/training complex.

The research of the article is armed at substantiating common methodological aspects of on-line and off-line teaching Maritime English (ME) to seafarers all over the world. These aspects concern linguistic, neurolinguistics and psychological characteristics of the trainees - non-native speakers who may study ME through IT ME Unified Communication Platform (UCP) for seafarers or in the class room with virtual or real present trainer which over lapping. The article contains working hypothesis as for linguistic modeling of ME teaching process to the students, non-native speakers.

We've tried to approach this position getting ready the teaching material for UCP within limits of case-marking system. This one in our opinion is to be construed coming from the event-argument structure in static metasystem to dynamic linguistic/developing system.

The effectiveness of this transition process can be defined positively when learners' language/sublanguage acquisition will exceed the combination of their initial training state and the input.

We would like to trace agents or elements of ME emergent behavior leading to self-organization and interaction in ME properly structured ways.

The extrainguistic factors affecting the conceptual reconstruction of integrated training pattern for students in video-conferencing lectures or 
practicals will be connected with such characteristics of learning types of students as:
I. Aspirations (A)
II. Reaction/Response (R)
III. Assessment (AS)
IV. Organization $(\mathrm{O})$

$\mathrm{V}$. Preference, based on information values complex $(\mathrm{P})$

Low, medium and high levels of A, R, AS, O, P will be depended and interlinked with the linguistic factors of the integrated training process generally and in distant learning mode in particular. They are:

I. Knowledge (K)

II. Understanding (U)

III. Application (AP)

IV. Synthesis (S)

When organizing the material for training complex we've tried to correlate these factors.

The intermediate results of the investigation demonstrated possible positive efficiency of the applied methodology in quantitative relation, further research will concern qualitative analysis.

\section{Comprehensive Approach to integrated teaching modeling within e-learning mode}

Modern conditions of higher education for future seafarers and the constant insistency for functioning specialists of Merchant Fleet to improve English Language practical skills strongly prove distant learning value. Learning modalities for such kind of professionals will vary from synchronous to asynchronous modes, from collaborative to individual learning of Maritime English (ME). Less collaborative, more individual learning of ME, especially by seafarers of different nationalities with their specific neural, macro- and microlinguistic skills will strongly depend on 5 qualities:

1. Quasi-permanent separation of teacher and learner or absence of "real" teacher at all (in asynchronous mode);

2. Influence of educational/shipping management in planning, preparation and provision of learner's support;

3. Possibilities in use of technical media;

4. Provision of two-way communication or independent learning;

5. Quasi-permanent absence of learning groups or connectivity of learners, gathered at random, just in the real "nick" time"

${ }^{1}$ Keegan D. Foundations of distance education ( $3^{\text {rd }}$ edition). London : Routledge. 1996. P. 21. 
Different nationalities, as it is well known and should be taken into account when modeling the teaching process, in this case of ME, have different tempo of speech, different from EL intonation, tempo of reaction, different levels of perceiving and acquiring the new knowledge, and what is especially important for structuring distant learning course, different degrees of self-regulation.

Fulfilling the task of distant e-learning teaching, we should understand the level and intensity of learners' thinking regulation, their motivation and behavior during learning. Just referring definitely to distant e-learning of ME by seafarers of different nationalities, we are strongly convinced to keep to the theory of integrative teaching on the basis of reserving the transcendental and integrative language constituent as means of creating "the effect of presence of multitudinal rows of objects" ${ }^{2}$.

Differentiation of objects in peripheral area of subject based / content based teaching becomes possible by means of language system on defining the semantic priming and semantic sones, building them with vocabulary, grammar and syntax.

We come from the theoretical research, where balance of extensive and intensive integration with synergistic model of education becomes possible when keeping to the principle of preserving the integral system complexity with dominating idea of possibility of existence forms, thinking hierarchy and activity $3,4,5,6$.

Integral processes inside this system cover context - thematic interdisciplinary zone of professional education in the mode/within the framework of overlapping so-called "sheltered" zones of language support, language of instruction and subject matter - based teaching.

The mode of overlapping these spheres made possible compressing the teaching information according to the principle of system quantization.

\footnotetext{
${ }^{2}$ Клепко С.Ф. Інтеграція і поліморфізм знання у вищій освіті. Філософія освіти. 2005. № 2. C. 20,32 .

${ }^{3}$ Берталанфи К.Л. Теория систем и системный анализ : учебное пособие для дистанционного обучения. Москва : Прогресс, 1969. С. 57. URL: http://fpi-kubagro.ru/teoriasistem-i-sistemnyj analiz.

4 Садовский В.Н. Системный анализ. Новая философская энщиклопедия : в 4 т. T. III. C. $35-71$.

5 Уёмов А.И. Системные аспекты философского знания. Одесса : Негоциант, 2000. 160 c. URL: http://philosof.onu.edu.ua/elb/uemov/uemov.pdf.

6 Эволюционная эпистемология и логика социальных наук: Карл Поппер и его критики / составление Д.Г. Лахути, В.Н. Садовского и В.К. Финна ; перевод с английского Д.Г. Лахути ; вступительная статья и общая редакция В.Н. Садовского ; послесловие В.К. Финна. Москва : Эдиториал УРСС, 2000. 464 с. URL: http://www.pseudology.org/psyhology/EvolutionEpistemology2.pdf.
} 
This fact as some scientists ${ }^{78}$, popularize will lead to increasing the information capacity of the motions formulated, deepening the essential side of these notions, improving the sequence of their development, building the conceptual thinking, comprehensing knowledge consistency, deepening the awareness of knowledge assimilation.

In this case we should rely on the principle of pedagogic cognitology 9 which provides textual induction and nominal determination of spatial time macro- and microstructures to be discussed further and highlight them as means of language support of professional; subject content-based teaching of future navigators. Integrated teaching of subject-based disciplines by means of sub-language of specialty should be arranged as simulated modeling of real professional cadet's activity.

The principle of pedagogic cognitology is aimed at the conceptual reconstruction of learner's subjective idea of the object or objects of the cognitive model of integrated teaching by means of

1. linguistic (collective and qualitative) analysis;

2. analysis of communication;

3. macro-structural analysis

The linguistic methods will allow, with the purpose of conceptual reconstruction of learners' subjective expectations, carry out the quantitative (content) analysis and qualitative (structural, lingvo-stylistic, semantic, logical) analysis of means of integrated teaching.

The analysis of communications supposes the discourse analysis of speech interaction of the subject of activity of integrated teaching with the objects of cognitive model, speech impact on the subject of teaching, monitoring the scientific truth through the analysis of formal concepts, constituents of the contextual teaching model. One more constituent of mechanisms of communication is argumentation within the explication framework and realization of generalized propositions, micro and macropropositions.

The macrostructural analysis together with linguistic methods and the analysis of communication is the integral of the contextual reconstruction of the model of the integrated teaching of students.

The cognitive mapping supposes the analysis and monitoring of the macro- and superstructures as the abstract global forms of connected text,

\footnotetext{
${ }^{7}$ Chomsky N. Three Factors in Language Design. Unpublished manuscript. 2007. P. 30.

${ }^{8}$ Scrivener J. Learning Teaching: The Essential Guide to English Language Teaching. $3^{\text {rd }}$ edition. MacMillan, 2011.

${ }^{9}$ Уёмов А.И. Системный подход и общая теория систем. Москва : Мысль, 1978. 272 c. URL: http://www.philosof.onu.edu.ua/elb/uemov/system_general_theory.pdf.
} 
composed of hierarchically organized / arranged set of categories, specific for the given genre, in our case, scientific and technical.

Typology and classification of categories supposes the analysis and management of the categories of genre environment, orientation, complications, events evaluation, the detailed evaluation of narrative actions from the point of view of its built-in in speech interaction. The final category may coincide with the category of conclusion of that argumented structure in which the given event / narration has been built in. The integrated contentteaching or in other words subject-based teaching assumes the linguistic action with realization of code mechanism of switching from one-language to two-language, multi-languages teaching curricula. And here we approach again the constituents of linguistic methods where words-terms, consisting of language minute semantic units of language are under research from the point of view of the denotative, connotative, significative meanings.

This means that carrying out content analysis of the integrated teaching, we select the language unit taking into account the meaning of notions terms, their meanings (connotations) and speaker's attitude to these meanings.

The next unit of the textual level following the discourse is the textema as the semantic unity of sentences, highlighted only in every definite text against the background of this text ${ }^{10}$.

We agree with the affirmation ${ }^{11}$ that the semantic structure of the text presents the system of conceptually significant meanings, arranged in the syntactically in a linear way method but organized while text functioning in a hierarchy.

So, when applying "ideal" means of teaching through the possibilities of material once we'll adhere to the mention principles of terms selection as separate lexico-grammatical units, combining them into specialized discourses, textemas and transition from them to professional texts adapted different levels.

The researches of many scientists as ${ }^{12},{ }^{13}$ are dedicated to the selection of texts on professional topics.

${ }^{10}$ Anohin P.K. In Bol'shaya Rossijskaja Jenciklopedia. Vol. 2. M., 2005. P. 18.

11 Берталанфи К.Л. Теория систем и системный анализ : учебное пособие для дистанционного обучения. Москва : Прогресс. 1969. С. 57. URL: http://fpi-kubagro.ru/teoriasistem-i-sistemnyj analiz.

${ }^{12}$ Lueddeke G.R. Professionalising teaching practice in higher education: a study of disciplinary variation and "teaching-scholarship". Studies in Higher Education. 2003. № 28 (2). Р. 213-228.

13 Пассов Е.И., Кузовлева Н.Е. Основы коммуникативной теории и технологии иноязычного образования. Москва : Русский язык. Курсы, 2010. С. 62-66. URL: osnovy_kommunikativnoi_teorii.pdf 
It is known that at present cognitology is based on theoretical models for complicated reality of human cognitive sphere.

It is without doubt that linguistic consciousness guides the functionality links, way of combining blocks/modules of elements of speech-mentallanguage system as the "ideal" means of teaching foreign language. It may be possible to define the most popular model of the activity aimed at teaching foreign languages.

It includes three different in quality complexes of functional blocks:

a) peripheral blocks of perceiving speech information and articulation of the speech sounds produced;

b) the language structures themselves which provide storing lexical information and grammatical word operations, their morpheme elements, interverbal connections, stereotypes of dynamic formations (sentence grammar), sequential sets of sentences (texts);

c) non-verbal structures, mostly closely connected with the semantic content of speech: cumulative-motivational block, blocks of cognitiveintellectual operations, representations of direct impressions, psychological states, personal peculiarities.

These structures as researches of above mentioned scientists, constitute, the model of teaching foreign languages activity, which may be successful in case of the systematic approach including application of teaching means: as "ideal", as material, technological.

The objective of our research is to trace and substantiate some aspects of linguistic modeling in connection neurolinguistics comprehension of foreign language/English language reality as frameworking of one side of blended teaching in on-line integrated decision.

The subject of the research is to elaborate the model of metacognitive skills of future navigators in Maritime terminology on the basis of the operational chart of their professional activity with the perspectives of their life-long professional education development. As for the tools in solving the tasks of pedagogical approach and strategy of "trainer-trainee" interaction on-line (or a classroom) it seems us appropriate to choose scaffolding with various levels of support. Besides levels of support which are reflection of the pedagogical approach we've referred to the forms of support:

- general support ("needs" and "musts");

- content support ("learning strategies");

- linguistic support ("building regarding the foreign language").

Linguistic support assumes prior activity like linguistic modeling of the teaching process of content-based education, in our case for future navigators. Having experience in teaching ME for students in Maritime Academy and summarizing our practical experience (and practical experience of our colleagues in teaching ME) for navigators in our parent academy we've made 
the attempt to finalize the linguistic modeling of our teaching process for nonnative speakers. As EL UCP is going to be aimed at reaching the gap between levels A1/ A2 and B1/ B2 and should be convenient tool for learning ME by low-ability and medium-ability learners, non-native speakers who may have some certain difficulties in perceiving, recognition behavior and response execution the following levels of support are appreciated as necessary for achieving positive results in teaching-learning:

- the teacher in classroom/trainer in virtual laboratory gives support to individual learners;

- the learners in classroom support each other through pair or group work;

- the learning activities should be differentiated (in classroom and to some extent in virtual lab) for more or less able learners;

- the content learned in English supports content learned in Mother language;

- the content itself supports the learning through Mother language;

- the format of task supports the learning of content in both Mother and English languages;

- the task are supported with visual and auditory effects.

The instructor/trainer who provides teaching ME on-line may have location in the native country and provide trainees' support in their native language. The approach and strategy of this support may be absolutely different depending on their origin: European, Asian, Mid-Asian, African. There should be taken into account national and individual trainees' difference in word recognition behavior, their stability degree of pronunciation $^{14}$ accuracy of production of phonological (for word naming) or semantic (for lexical decision) which be taken to reflect response times in their behavioral lexical processing.

Every teacher-trainer interacting with his trainee/s decides (during his preparatory activity) how to indicate the greater efficiency of access, more salient representation of the lexical item (or definite portions of the whole thematic corpus) and greater availability of the representation within the individual learner's vocabulary ${ }^{15}$. This task can be solved, in our opinion, by creating favorable learning environment with positive impact on psychological

${ }^{14}$ Chen H.C.; Leung Y.S. (1989) Patterns of Lexical processing in a nonnative language. Journal of Experiment Psychology : Learning, memory and Cognition. 12. P. 397-401.

${ }^{15}$ Monaghan P.; Chang Ya-Ning, Welbourne S.; Brysbaert M. Exploring the relations between word frequency, language exposure and bilingualism in a computational model of reading. April 2017. Journal of Memory and Language 93. P. 3, 10. URL: http://doi.org/10.1016/j.jml.2016.08.003. 
factors affecting word presentation. Word frequency effect, word embedding, word exposure in the whole teaching thematic model should be supported by auditory accuracy of phonological (for word naming) or semantic (for lexical decision) representation to reflect response times in behavioral lexical processing from the previous model experience to the present. Local Trainers should generalize sub-lexical routes they follow with the trainees. These routes map letters to sounds via a set of grapheme-phoneme correspondence rules and lead to a lexical route containing word units. It can directly activate the phonology corresponding to the whole words. So we come to the one of the most important components of linguistic modeling - imageability in close connection with sensology - sensitivity.

\section{Formation of Teaching Strategy in Integrated distant learning of Maritime English}

The advantages of implementing computer-based communication through distant-learning technologies are considered out by many native and foreign scientists ${ }^{16,17,18,19,20,21}$.

The matter to what extent each kind of distant learning-teaching will be efficient, depends on four factors:

- the effectiveness of teacher-student collaboration irrespective of the distance between them;

- pedagogical technologies implemented herewith;

- the effectiveness of didactic materials worked out for distant learning purposes and methods/ways of their presentation;

- the efficiency of feedback.

${ }^{16}$ Alexander F.K. The Changing Face of Accountability: Monitoring and Assessing Institutional Performance in Higher Education. July 2000. The Journal of Higher Education. 71 (4): 411-431.

${ }^{17}$ Arshad K.; Imran M. A. Increasing the interaction time in a lecture by integrating flipped classroom and just-in-time teaching concepts. June 2013. Compass Journal of Learning and Teaching 4 (7): 1-18. URL: https://journals.gre.ac.uk/index.php/ compass/article/view/84.

${ }^{18}$ Deem R.; Mok K.H.; Lucas L. Transforming Higher Education in Whose Image? Exploring the Concept of the 'Word-Class' University in Europe and Asia. March 2008. Higher Education Policy 21(1): 83-97. URL: http://citeseerx.ist.psu.edu/viewdoc/ download?doi=10.1.1.456.5712\&rep=rep1\&type=pdf.

${ }^{19}$ Keegan D. Foundations of distance education ( $3^{\text {rd }}$ edition). London : Routledge, 1996. P. 21.

${ }^{20}$ Scuratov A.K. (2003) Methodological researches in the context of distant learning. Saint Petersburg. 2003. № 3. P. 24-30.

21 Zhang D.; Zhao J.L.; Zhou L.; Nunamaker Jr. J.F. Can E-learning Replace Classroom Learning? May 2004. Communications of the ACM 47 (5): 75-79. 
For our research we highlighted three main components which support the effectiveness of distant learning in technical universities of Ukraine:

1. Linguistic economy and effectiveness.

2. Psychological abilities, restrains and limitations.

3. Content and language based integrated process.

The question is how to overcome the difficulties in construing these components, interlinking in one corporate body, providing the supportative learning environment, implementing the transcendental cognitive technology of content-based learning of future specialists.

We refer to the classification of implementing distant learning, contentbased as experimental and expository learning. Every tutor engaged in distant learning should clearly define for himself what language will be enough and effective to express subject-matter content and how it will work in teaching-learning process.

At the second stage, expository learning tutor will come to the abstract language and decontextualized discourse. As a result of positive of these stages linguistic progression - from language to abstract discourse becomes vivid.

The formation of future navigators' discourse competence is the core of our research and is connected with developing and argumenting the discourse strategy in teaching maritime English. The starting point in this process to realize the inter-connection of three main positions "concept" "frames" - "discourses". As well known, "any concept has its basic layerthe definite sensitive image". This image is considered out as the unit of the universal subject code 22 "coding this concept for thinking operations"23.

Such unit of the universal subject code for planning and training professional language activities of future navigators correlates with the image "Ship". It represents the fragment of definite professional culture of the world. This concept as any others in the theory of the world conceptualization can be categorized in frames ${ }^{24}$.

Scientists associate the term "frame" with such terms as "scenario/script", "situational model", "cognitive model", "scene-prototype", "scheme" 25 .

${ }^{22}$ Попова З.Д., Стернин И.А. Когнитивная лингвистика. Москва : АСТ : ВостокЗапад. 2007. С. 8-12.

${ }^{23}$ Чейф Ч.Л. Память и вербализация прошлого опыта. Новое в зарубежной лингвистике. Вып. ХІІ. Москва, 1983. С. 35, 73.

${ }^{24}$ Филлюр Ч. Фреймы и семантика понимания речевых актов. НЗЛ. Вып. ХХIII. Москва, 1988. С. 52-90.

${ }^{25}$ Дейк ван Т.А. Фреймы знаний и понимание речевых актов. Язык. Познание. Коммуникация. Москва : Прогресс, 1989. С. 12, 40. 
Van Dijk considers that within the limits of the spontaneous or organized discourse any communicative action can be presented as the implementation of these or those communicative-cognitive structures ${ }^{26}$. Such cognitive structures are the frame models which contain the information socio-cultural including professional or so-called knowledge of "language games".

We can agree with interpreting the term "frame" as "situational model" and the term "discourse" as the set or "string" of the defined situational models which in case of our research accumulate high professional linguistic and cognitive load.

Hierarchy in each situational model is determined by scenario frames "terminals" or "slots". The levels of the "scenario" structures are defined by Minsky $^{27}$ as following:

1. Surface-syntactic frame as combination "verb-noun", including prepositional structures;

2. Surface-syntactic frame: the meaning of the words, characterizing definite action. They are qualifying the relations of the participants, strategy of their movement, its purposes, consequences and accompanying effects;

3. Thematic frames-scenario and connected with the topic, activity portraits, surroundings;

4. Frame of narration - framework of the stereotype stories, explanations and proofs to construe the comprehensive thematic frame. The concept "ship" as the whole image of seafarers' professional world can be supported by the frames.

Our aim in distant mode of learning - learning progression - from experimental to expository.

In integrated teaching the most successful output can be reaching with further approach to the content progression which involves a range of thinking skills.

In our scientific investigation we keep to the idea of creating integrated information environment of virtual simulation/training complex. Integrated training system of this complex will include:

1. Data-base acquisition;

2. Training of student's knowledge;

3. Training of their skills;

4. Training of students' readiness to self-studies.

As for the ways of communication in this integrated information environment of virtual simulation/training in distant learning mode, they are defined depending on the participants of this process.

${ }^{26}$ Van Djik, T. Social cognition and discourse. H. Giles and R.R. Robinson (eds) Handbook of Social Psychology and Language. Chichester : Wiley, 1989. P. 164-165.

${ }^{27}$ Minsky M. The Emotion Machine. Simon and Schuster. November 2006. P. 1, 25. 

A. Tutor $\rightarrow$ students
B. Tutor $\leftrightarrow$ students $\leftrightarrow$ students
C. Student-expert $\rightarrow$ students
D. Tutor $\leftrightarrow$ peer group support $\rightarrow$ students
E. Students $\leftrightarrow$ coordinator/moderator/facilitator $\leftrightarrow$ students (chat comprehension)

In our teaching process we are closer to type E (author's classification) though try to float/ vary in-between all types defined.

Neurolinguistics should be based on defining types of learners, learning styles, distant control of learners, and their learning experience.

Pragmalinguistics investigates problems of means affecting the addressee, types of verbal reaction on the stimulus, the questions of successful actions of speaking, interpretations, also the types of verbal communication (dialogue, conversation, arguments, and discussion) ${ }^{28}$.

The linguistic, communication, microstructural analyses of the textual material will facilitate to elaborate the cognitive pattern and mechanism of the integrated teaching process of distant virtual simulation.

The ways of using the language units will define students' verbal actions based on realizing mental communicative-cognitive process.

The extra linguistic factors affecting the conceptual reconstruction of integrated training pattern for students in video-conferencing will be connected with such characteristics of learning types of students:

1. Aspirations (concentration of learners' attention) (A)

1.1 Recognition (of the task/set, problem, teaching direction)

1.2 Volition to achieve them

1.3 Attention at student's choice and will

2. Reaction/ Response (R)

2.1 Agreement to answer

2.2 Volition to answer

2.3 Satisfaction from answer

3. Assessment (AS)

3.1 Acceptance of information values

3.2 Priorities on them

3.3 Obligatory information signposts

4. Organization $(\mathrm{O})$

4.1 Conceptualization of information values

4.2 Elaboration of learners' system of values

5. Preference, based on information values complex $(\mathrm{P})$

\footnotetext{
${ }^{28}$ Morris D. The Naked Ape: A Zoologist's Study of the Human Animal Jonathan Cape Publishing. 1967. P. 6.. URL: https://folk.ntnu.no/krill/biokoreferences/Morris\%201967.pdf.
} 
5.1 Generalized set

5.2 Priority ${ }^{29}$

Low, medium and high levels of A, R, AS, O, P will be depended and interlinked with the linguistic factors of the integrated training process generally and in distant learning mode in particular. They are:

I. Knowledge (K)

1.1 of the definite material

1.2 terminology

1.3 facts

1.4 ways and means of getting knowledge of this material

1.5 system of definitions and categories

1.6 criteria

II. Understanding (U)

2.1 Explanation

2.2 Interpretation

2.3 Extrapolation

III. Application (AP)

IV. Synthesis (S)

Table 1

Correlation of linguistic and extra linguistic factors

\begin{tabular}{|c|cc|cc|}
\hline I. & Knowledge & $\longleftrightarrow$ & $\longrightarrow$ & Aspirations \\
\hline II. & Understanding & $\longleftrightarrow$ & $\longrightarrow$ & Reaction \\
\hline III. & Application & $\longleftrightarrow$ & & Assessment \\
\hline IV. & Analysis & $\longleftrightarrow$ & & Organization \\
\hline V. & Synthesis & $\longleftrightarrow$ & $\longrightarrow$ & Preference \\
\hline
\end{tabular}

If the background knowledge of the learners at the beginning of the session or a number of sessions on the professional topic is adequate to the learners' aspirations, the topic will be recognized thematically and logically by the students both sides of video-conferencing "table".

The tasks will be recognized, volition to achieve them will be demonstrated and tutor will be able to focus learners' attention on the signposts of the conference session not only forcibly but at their will and choice.

The tutor who can fulfill the functions of moderator/ coordinator/facilitator will watch the teaching environment, how the groups understand the information, tasks set to them and moderates the communication process, learners' reaction to normal tempo of exchanging subject-matter information.

${ }^{29}$ Stones E. Verbal labeling and concept formation in primary learning and teaching programmed introduction. New York, 1968. P. 11. 
Next step - simulation of professional duties, application of training session information, facts, ideas, terminological concepts and assessment of information values, prioritizing them and acknowledging the obligation to acquire them within the syllabic framework.

Analysis of the information values, pragmatic ideas by the students (Group A - in Odessa, Group B - in Mariupol, in our case), moderated and facilitated by the tutor will direct from language in action to language in action to language abstract, from linguistic progression to content-based progression, organizing or approaching the system of training session values for the learners.

The synthesis of the knowledge, information values got by the learners in "triangle coordination": students (Group A) $\leftrightarrow$ tutor $\leftrightarrow$ students (Group B) makes possible to clear their preference. They can formulate the generalized set of the training session or a cycle of sessions generally integrated teaching process and in distant learning mode, in particular.

\section{Results for distant learning on the topic "Passing through Narrow \\ Channels and Canals" with cadets of the $5^{\text {th }}$ year of Navigation Department, Odessa Maritime Academy and Mariupol Affliation}

The following attachments on the topic "Passing through Narrow Channels and Canals" partly demonstrate the organizational structure of the work with the video-conferencing training complex (including Presentation "Passing through Narrow Channels and Canals") with groups of students mentioned above.

The content analysis of the presentation "Passing through Narrow Channels and Canals" proves that its integrated information environment is rather complicated for perception and requires some definite knowledge of students, both groups, and first of all, linguistic one.

To introduce learners into the topic becomes possible when giving them the set for comprehension and vocabulary interpretation.

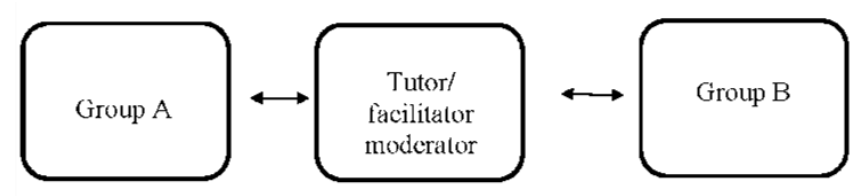

Fig. 1. Scheme of communication

We consider Tutor the source of information. Key term collocations provide so-called "orientation on the topic and students' further aspirations". 
Using $\mathrm{T}$ (Newcomb) model (social- psychological) of communication, we shall take into account the relationship between the agents of communication (group A and B) and the object of speech (X).

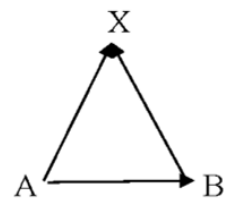

Fig. 2. Social - psychological model of communication

These agents are almost unknown to each other individually but the teacher's role as the subject of speech and communication is to define clearly their levels of understanding of the teaching material, combine their present opinions with his own and try to develop now social foundation for learning.

The tutor demonstrates the following types of tasks for reaction (like memorizing the terms, matching the synonyms of the original terms, matching the terms with their definitions, matching the word meaning with the proper example of its use, then at expository stage - assessing the professional situations, simulating professional dialogues, making the analysis of the professional statistics, case studies). When we combine two groups or maybe more in one video-conferencing table, we should think not only about their immediate reaction, team work one side, we should tune them in one mode of positive relationship to each other and their efforts of agents of communication to coincidence of their relationship towards X.

Tutor will balance the agents' effects (groups A and B) in communication orientation and guide them towards the next stage of integrated communicative process - complication. Tutor will set the next task to the learners (groups A and B) through the process of codification of the teaching information. He is the subject of speech here which has already developed in interaction with Group A and B the initial concept of topic "Passing through Narrow Channels and Canals", connected with:

a) COLREGs

b) Sound and Light Signals

c) Violation of Rules, Statistics

d) Traffic Separation Schemes

e) Accidents and Incidents at Sea

f) VHF Communication

This stage is connected with learners' efforts to apply more complicated portion of teaching material and together with the tutor to assess the 
integrated teaching environment. New terminological collocations expressing necessary actions are worked out in the next task, the tutor will monitor which group of learners is more amorphous, and which is peergroup support. Application of word combinations in context matching the situation with its identification, continuing the phrase with the appropriate ending will provide the assessment (complete or partial) of the teaching material, and their own communicative abilities by group $\mathrm{A}$ or $\mathrm{B}$ in competitive partnership with each other and tutor.

Acquiring the presented teaching material more or less successfully both groups or one of them first, start the events evaluation, analyzing them with different degree of organization. Subject - matter material will be evaluated by the students coming from the linguistic knowledge; complexity of the teaching material:

1. percentage of difficult 3-, 4-, 5- syllable words;

2. proportion of terminological collocations in comparison with units of general English;

3. proportion of complex, compound and simple sentences;

4. average length of paragraphs;

5. average length of the text;

6.complexity of the text.

Coming from the above-mentioned principles of modeling integrative processes of teaching educational and speaking activity, we present our topics (APPENDIX 1 "Passing through Narrow Channels and Canals") at the following stages:

1. linguistic-conceptual;

2. EL receptive;

3. EL reproductive;

4. linguistic-expressive;

5. EL productive;

6. EL reflexive ${ }^{30}$.

The $1^{\text {st }}$ stage will be connected with the presentation of key terms and collocations in connotative frame work which provokes the learner to start his process of embedding into rhema-thematic field of professional activity. That's like the first stage of linguistic modeling of the topical competency.

Then creating thematic clomain will be continued with intensifying interactive cooperation of trainer $\rightarrow$ trainee $1 \rightarrow$ trainee $2 \rightarrow \ldots$ at the $2^{\text {nd }}$ stage. The key terms will be organized into "multitudinal rows of objects" as

30 Мартынова Р.Ю. Моделирование звеньев организационного и содержательного блоков процесса обучения образовательным дисциплинам. Наука $i$ освіта. 2020. № 3. C. 155-163. DOI: URL: https://scienceandeducation.pdpu.edu.ua/doc/ 2020/3_2020/22.pdf. 
terminological patterns in discourses on the textual basis to initiate highlighting trainee's sensitivity to the case-argument effect of the thematic words activity, their practical application as a physical action.

At the $3^{\text {rd }}$ stage of our linguistic modeling the definite topic, its thematic domain will be progressed to presenting behavioral events within the framework of the topic. That will give the trainee the chance to trace the lexical and sub-lexical routes thematically with a certain degree of linguistic consciousness and fluency.

We as trainers start to upbring learners' self-regulated thinking when coming to the $3^{\text {rd }}$ and then to the $4^{\text {th }}$ stages of integrated teaching activity linguistic-expressive. That's connected with frame-scenario, with simulation of executing professional duties attitudinally, expressing personal emotions towards the professional situation.

At the $5^{\text {th }}$ and the $6^{\text {th }}$ stages, EL productive and EL reflexive ones we assume to come from training learners' linguistic skills to training trainees' readiness to self-studies which is especially important in distant learning mode. And this is high point in integrated teaching process when focusing learner's attention on the task, its recognition and his volition to achieve the positive solution basing on the linguistic competence and tracing interdisciplinary connections and creating subject-based image.

\section{Interpretation of results for distant teaching-learning the topic "Passing through Narrow Channels and Canals" by two groups in video-conferencing Odessa - Mariupol}

This "on-line" teaching was rather provocative for the weaker group and rather supportive for them. Group A demonstrated quicker reaction and encouraging Group B to participate energetically. The "triangle partnership" motivates stronger group to demonstrate their knowledge of the terms, weaker one to match the terms with their definitions, "all together" efforts to show their aspirations to acquire the topic more or less perfectly. Understanding of the definitions by one group quicker will improve the competitiveness in demonstrating their reaction. Sometimes both groups react almost simultaneously and it leads to the enforcement of the understanding and makes steady application of the topical terminological collocations more impressive for the both classes. This encouraged even weaker group - Group B be interested in making up situations with these collocations and assessing their own possibilities to master the topical problems in verbal mode. That was interesting to supervise the process of analyzing the material by Group A, which construed the chunks of sentences in correct order. Group B were immersed in this procedure fully, participated in correcting the mistakes, translating the vague points. 
Summarizing the acquired knowledge, understanding the professional issues on the basis of the linguistic competence groups came to the important point synthesis. Groups A and B demonstrated almost in parallel actions competency of the textual material, reading it, completing the sentences, discussing the high points of the textual information and showing their preferences.

In general, tutor and her assistants evaluated the efficiency of "on-line" discussion which was rather vivid.

\section{Analysis and discussion}

How really is it possible to evaluate the efficiency of on-line teaching when the tutor is drawn away from students by certain distance?

We propose to keep to the formula like:

$$
\mathrm{F}=\frac{V_{m} * a_{m} * t}{p_{v} * w \sqrt{d}},
$$

where $\mathrm{F}$ - efficiency of the teaching-learning process for both groups/ sides, $V_{m}$ - amount/ volume of material portion, $a_{m}$ - accessibility of the teaching material for the students present, $t$ - time period for teaching this material portion, $p$ - average number of persons present at the moment, $v$ - number of the students really active participants of the teaching-learning process, $w$ - average age of the students, $d$ - distance, virtual or real which divide the participants.

\section{CONCLUSIONS}

Under time pressure, limited rest periods, restricted access to Internet resources maritime officers and their apprentices should be provided with detailed, diligently constructed and economically tailored teaching material, updated and refreshed constantly.

The core of this material is/will be based on current primary information, which reflects interdisciplinary connections. These connections are traced through topical key terms organized to define the thematic domain in which the learner should be embedded.

The key terms stringed into terminological patterns should be sustainable enough to provide these patterns recognition by distant learners as neural events and their transformation to behavioral events.

At some definite stage of teaching process, the learner should feel himself not only as a knowledge consumer but as an active participant of his knowledge development process. In such case teacher/tutor in synchronous mode and the learner himself as a "self-regulator" in asynchronous mode will feel possible modeling his linguistic behavior. The presence of an access to local teacher/tutor in on-line teaching should diminish or mitigate national variables (as specific linguistic difficulties, cultural gaps, etc.) provide 
learner's higher order thinking as "a mechanism spanning brain"31 and assist in transferring his understanding to the physical routine and environment, making his understanding conscious and building his understanding as spontaneous and fluent.

We are sure that these cognitive capacities of humans will be effectively realized, if language/sublanguage system will be organized in horizontal and vertical dimensions integrated. Static meta-system as a part of complex system first should be used to place the learner inside the specific context horizontally where benchmarks are the popularized words consistent with learners' intentions. Minimal set of core thematic words forming a string of interrupted theme-rhemes will give the linguistic nativist possibility to overcome retardation in adaptability to linguistic progress from his initial language acquisition state to the expected input ${ }^{32}, 33$.

Meta learning at the first stage of learning process itself (i.e. devoted to ME teaching-learning) will be facilitated by the teacher/tutor's efforts to decoding specific terminological information by decontextualizing it. And this process will involve, in our opinion, simplification in perceiving ME sub-specialty structure. It is especially valuable for non-native speakers, students/learners who has difficulties of phonological, grammatical character.

\section{Passing through Narrow Channels and Canals}

APPENDIX 1

Coming from the above-mentioned principles of modeling integrative processes of teaching educational and speaking activity, we present our topics (APPENDIX 1 "Passing through Narrow Channels and Canals") at the following stages:

1) linguistic-conceptual;

2) EL receptive;

3) EL reproductive;

4) linguistic-expressive;

5) EL productive;

6) EL reflexive.

\section{Linguistic-conceptual stage.}

31 Diesel, H. Linguistic nativism. 2015. P. 14. URL: http://www.personal.unijena.de/x4diho/LA_Linguistic_nativism.pdf.

${ }^{32}$ Kerr B. (2007, February 3) MS 4.7 Re: What Connectivism is. Online Connectivism Conference : University of Manitoba. P. 17. URL: http://ltc.umanitoba.ca/moodle/mod/ forum/discuss.php?d=12.

${ }^{33}$ Kop R.; Hill A. Connectivism: Learning Theory of the Future or Vestige of the Past? October 2008. International Review of Research in Open and Distance Learning 9 (3). P. 7, 10. URL: https://www.researchgate.net/publication/26544860_Connectivism_ Learning_Theory_of_the_Future_or_Vestige_of_the_Past. 
Dear cadets, now we start to learn the topic on your specialty "Passing through Narrows and Canals". To be able to interact with your class-mates, and in future with your colleagues on the ship on this topic, we introduce key words and expressions first to study them, and then to apply in different situations in this very topic.

1. Read and translate, referring to the manual, apply direct and indirect translation, by hearing.

Useful Words

\begin{tabular}{|c|c|}
\hline narrow channel & узкость \\
\hline fairway & фарватер \\
\hline underway & на ходу \\
\hline give-way & уступающее дорогу \\
\hline stand-on & идущее своим курсом \\
\hline to cross & пересекать \\
\hline on-coming & встречное (судно) \\
\hline to proceed & следовать \\
\hline to adhere to & придерживаться, соблюдать \\
\hline intention & намерение \\
\hline to overtake & обгонять \\
\hline buoy (with light and whistle) & буй (со световым и звуковым сигналом) \\
\hline bearing & пеленг \\
\hline
\end{tabular}

\section{Useful Word Collocations}

\begin{tabular}{|l|l|}
\hline to keep clear of & держаться в стороне от \\
\hline constrained/congested waters & ограниченная акватория \\
\hline traffic lane & полоса одностороннего движения \\
\hline traffic separation scheme (TSS) & зона разделения движения \\
\hline $\begin{array}{l}\text { Compliance/Non-compliance } \\
\text { with Collision Regulations } \\
\text { (ColRegs) }\end{array}$ & $\begin{array}{l}\text { соответствие/несоответствие Правилам } \\
\text { предотвращения столкновений судов } \\
\text { (МППСС) }\end{array}$ \\
\hline $\begin{array}{l}\text { with particular alertness } \\
\text { and caution }\end{array}$ & $\begin{array}{l}\text { с особой бдительностью } \\
\text { и осторожностью }\end{array}$ \\
\hline to reduce speed & снижать скорость \\
\hline to navigate safely & осуществлять навигацию безопасно \\
\hline to impede the passage & препятствовать движению \\
\hline to sound an appropriate signal & подавать соответствующий сигнал \\
\hline to relieve of obligation & освобождать от обязательства \\
\hline to near a bend & приближаться к повороту \\
\hline to keep out of the way & уходить, освобождать дорогу \\
\hline $\begin{array}{l}\text { to maintain/keep one's course } \\
\text { and speed }\end{array}$ & идти своим курсом и скоростью \\
\hline to alter one's course & изменить курс судна \\
\hline
\end{tabular}


2. Read the sentences, replacing words in native language into English variants.

1. Traffic separation scheme is divided into two or three separate (полосы разделения движения).

2. The traffic station asked the ship (изменить ее курс).

3. A vessel shall as far as practicable avoid (пересекать) traffic lanes.

4. Ship's (пеленг) does not appreciably change.

5. I should alter my course (на правый борт).

6. The vessel shall (уступить дорогу) to the ferry and avoid crossing (впереди) of her.

7. (Несоблюдение МППСС) often leads to a near-miss or a closequarter situation.

8. The tanker was (обгонял) a small vessel on her starboard side.

9. Every give-way vessel must take early and substantial action (держаться на достаточном расстоянии) of a stand-on vessel.

10. The stand-on vessel shall keep (сохранять, поддерживать курс и скорость).

3. Find the appropriate term usage from every three variants.

1. I intend to overtake you on your starboard side.

I try to overtake you on your right side.

I wish to overtake you on your bow side.

2. The vessel may use the sound signal prescribed in Rule 34(d) if in doubt as to the intention of the crossing vessel.

The vessel may use the sound signal nominated in Rule 34(d) if in doubt as to the wish of the crossing vessel.

The vessel may use the sound signal described in Rule 34(d) if in doubt as to the goal of the crossing vessel.

3. A vessel nearing a bend or an area of a narrow channel or fairway shall navigate with particular alertness and caution.

A vessel nearing a bend or an area of a narrow channel or fairway shall navigate with extreme attention.

A vessel nearing a bend or an area of a narrow channel or fairway shall navigate under pressure and due concentration of attention.

4. This Rule does relieve the overtaking vessel of her obligation to keep clear of the overtaken vessel.

This Rule does not free the overtaking vessel of her responsibility to keep clear of the overtaken vessel.

This Rule does not exempt the overtaking vessel of her burden to keep clear of the overtaken vessel. 
5. The Pilot wants us to rig pilot ladder on the portside 3 metres above the water while approaching TSS.

The Pilot wants us to fix pilot ladder on the portside 3 metres above the water while entering the narrow channel.

The Pilot wants us to connect pilot ladder on the portside 3 metres above the water while entering the traffic lane.

6. A give-way vessel shall not impede the passage of a stand-on vessel.

A give-way vessel shall not prevent the passage of a stand-on vessel.

A give-way vessel shall not obstruct the passage of a stand-on vessel.

7. There is an oncoming vessel ahead of us.

There is a meeting vessel ahead of us.

There is entering vessel ahead of us.

8. Reduce the speed and alter course to 10 degrees to starboard!

Diminish the speed and alter course to 10 degrees to starboard!

Retard the speed and alter course to 10 degrees to starboard!

9. Ship's manning must be highly professional to navigate safely in the constrained waters.

Ship's manning must be highly professional to navigate safely in the limited waters.

Ship's manning must be highly professional to navigate safely in the aggravated waters.

10. While proceeding through narrow channels vessels shall adhere to Rule No.9 of the International Regulations for Preventing Collisions at sea (ColRegs).

While proceeding through narrow channels vessels shall stick to Rule No.9 of International Regulations for Preventing Collisions at sea (ColRegs).

While proceeding through narrow channels vessels shall keep to Rule No.9 of International Regulations for Preventing Collisions at sea (ColRegs).

II. EL receptive stage.

At the previous stage, we have worked out the new words and expressions to the topic and now we should trace attentively their usage in practical guidelines and presentation of the topic.

\footnotetext{
1. Motivate the necessity to learn the topic "Passing through Narrows and Canals".

i.e. When coming from a passage plan if a ship is to pass a narrow the deck officer should take into account the fact that in constrained waters the
} 
ship may be in a position beyond which it will not be possible to do other than proceed.

The position is termed the point of no return because the ship enters waters so narrow that is sometimes difficult to maintain her course and speed due to a falling tide and insufficient Under Keel Clearance (UKC).

Under Safety Management System (SMS) this ship's operation is considered as critical due to its complexity and possible inability to alter her course.

So 2 hours prior to entering the narrow Officer on the Watch (OOW) of the ship calls VTS (vessel traffic scheme) at the pilot station and should give them all the required information about the ship.

To get ready for a safe passage he should consult the chart, the passage plan and the contingency plan, informs the engine-room that the engines must be ready for maneuvering, check the navigational equipment, steering gear, including manual, auto-steering gear and emergency changeover arrangements, navigational and signal lights, communication facilities. His responsibility for the safety of ship's navigation cannot be overestimated.

\section{Listen and study lecture-presentation to the topic.}

\section{PASSING THROUGH NARROW CHANNELS AND CANALS}

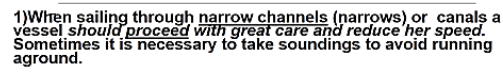

2) In some channels or canals with intensive traffic special traffic separation schemes have been recently introduced. it means that in these congested waters ail the area is

divided into two or three separate lanes along which ships may proceed only in one direction. Shore based radar
stations usually help the vessels there to navigate safely in stations usu
these lanes.

\section{Slide 1}

This Rule contains the following recommendations:

(a) A vessel proceeding along the course, of a narrow channel or fairway shall keep as near to the outer limit of the channel or fairway which lies on her starboard side as is safe and practicable.

(b) A vessel less than 20 metres in length or a sailing vessel shall not impede the passage of a vessel which can safely navigate only within a narrow channel or fairway.
The International Regulations for

Preventing Collisions at sea

(commonly called COLREGS).

While proceeding through

narrow channels

vessels shall adhere to Rule No, 9

of the

International Regulations for

Preventing Collisions at Sea.

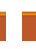


(d) A vessel shall not cross a narrow channel or fairway if such crossing impedes the passage of a vessel which can safely navigate only within such channel or fairway.

The latter vessel may use the sound signal prescribed in Rule 34 (d) (i.e. at least five short and rapid blasts on the whistle or a light signal of at least five short and rapid flashes) if in doubt as to the intention of the crossing vessel.

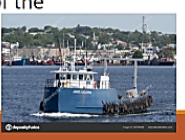

Slide 5

(e)(i) In a narrow channel or fairway when overtaking can take place only if the vessel to be overtaken has to take action to pe rmit safe passing, the vessel intending to overtake shall indicate her intention by sounding the appropriate signal pres cribed in Rule 34 (c) (i) (i.e. two prolonged blasts followed by one short blast to mean: "I intend to overtake you on your starboard side",
$\mathrm{S} / \mathrm{B}$ side

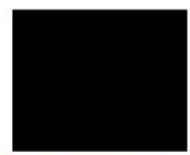

or two prolonged blasts follon

$$
\text { Port side }
$$

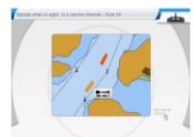

\section{Slide 7}

\section{Buoys in narrows and canals. What are buoys?}

They are floating objects moored to the sea-bed. They are signposts of the sea which are used to mark fairways and channels, shoals and banks, rocks, wrecks and other obstructions to a safe channel.

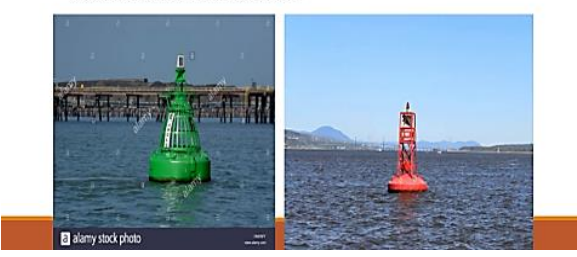

Slide 9 (g) Any vessel shall, if the circumstances of the case admit, avoid anchoring in a narro

The Regulations contain many other rules of which we shall mention now only a few

derway" when she is not at anchor, or made fast to the shore, or agrou

A vessel "at anchor" in dependence of her length shall carry one or two white lights all round the horizon, one at the foremast stay and the other at the stern.

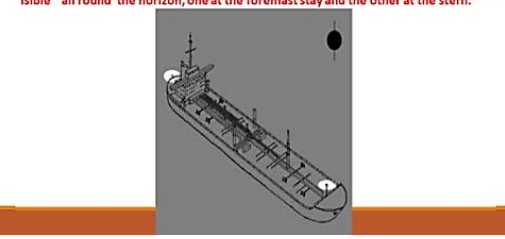

Slide 6

A vessel nearing a bend or an area of a narrow channel or fairway where other vessels may be obscured by an intervenin obstruction shall navigate with particular alertness and caution and shall sound the appropriate signal prescribed in Rule 34 (e) (i.e. one prolonged blast which shall be answered with a prolon ged blast by any approaching vessel)

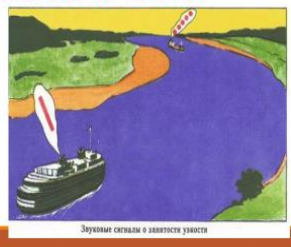

Slide 8

1) a definite shape or a colour so that you could recognize them;

2) top marks fitted to tell you are at the inner or outer end of a channel;

3) lights, bells or whistles attached to show their position in darkness;

4) radar reflectors so that they can be picked out with modern navigational equipment.

\section{Slide 10}




\section{Read the contents of each slide and answer questions to them.}

I slide:

1. Should a vessel proceed with great care and alertness when sailing through narrows?

2. Have Traffic separation schemes been introduced recently or long ago?

3. In the congested waters all the area is divided into two or three separate lanes along which ships may proceed only in one direction, isn't it?

II slide:

1. Are International Regulations for Preventing Collisions at sea commonly called ColRegs?

2. Shall vessels adhere to Rule 8 or 9 while proceeding through narrow channels?

3. Vessels shall adhere to Rule 9 of ColRegs in narrow channels, shan't they?

III slide:

1. Shall a vessel proceeding along the course, of a narrow channel or fairway keep as near to the outer limit of it?

2. Does outer limit of the channel or fairway lie on the vessel's starboard or port side?

3. A sailing vessel shall not impede the passage of a vessel, which can safely navigate only within a narrow channel, shan't she?

IV slide:

1. Shall a vessel engaged in fishing not impede the passage of other vessels navigating within a narrow channel or fairway?

2. Does a fishing vessel or sailing vessel not impede the passage of other vessel proceeding along the fairway?

3. A vessel engaged in fishing shall not impede the passage of any other vessel within a narrow channel, shan't she?

V slide:

1. Shall a vessel not cross a narrow channel or fairway if such crossing impedes the passage of a vessel within such channel or fairway?

2. May the vessel, which can safely navigate only within a narrow channel, or fairway use the sound signal prescribed in Rule 9 or 34(d) if in doubt as to the intention of the crossing vessel?

3. The sound signal, at least five short and rapid blasts on the whistle or a signal of at least five short and rapid flashes is given if in doubt as to the intention of the crossing vessel, isn't it? 
VI slide:

1. Shall any vessel, if circumstances admit, avoid anchoring in narrow channel?

2. Is vessel "underway" when she is not at anchor or made fast to the shore or aground?

3. A vessel "at anchor" in dependence of her length shall carry one or two white lights visible all-round the horizon, shan't she?

VII slide:

1. Has the vessel being overtaken to take action to permit safe passing in narrow channel or fairway?

2. Does the appropriate signal "two prolonged blasts followed by one short blast" mean the intention to overtake the other vessel on her starboard or port side?

3. The vessel intending to overtake shall indicate her intention by sounding the signal prescribed in Rule 34(c), (i), shan't she?

VIII slide:

1. Shall a vessel nearing a bend obscured by an intervening obstruction sound one prolonged blast?

2. Shall a vessel nearing an area of a narrow channel or fairway navigate without intensive attention or with particular alertness and caution?

3. One prolonged blast of a vessel nearing a bend shall be answered with a prolonged blast by any approaching vessel, shan't it?

IX slide:

1. Are buoys floating objects moored to the sea bed? also?

2. Are buoys used to mark only obstructions or fairways and channels

3. Buoys are signposts of the sea, aren't they?

$\mathrm{X}$ slide:

1. May the buoys have a definite shape, colour?

2. Are top marks fitted to tell you are at the inner or outer end of a channel?

3. Lights, bells or whistles are attached to the buoys to show their position in darkness, aren't they?

\section{EL reproductive stage.}

Now dear friends, after acquiring skills of applying the terms in the ready-made material we come to the tasks of expressing your independent ideas based on the keys terms and terminological collocations studied at the previous stages. 
1. Give written answers to the questions to each slide, describing the contents of them.

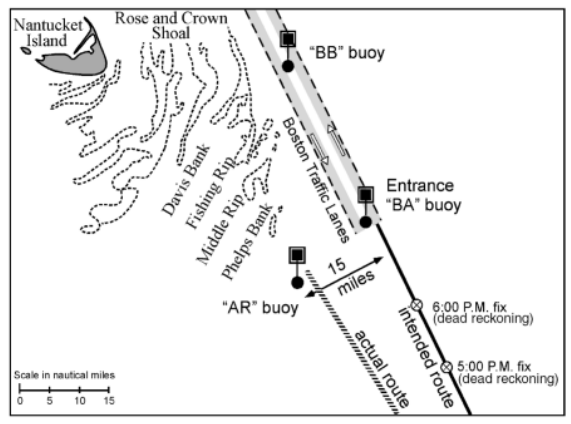

1. What was the Royal Majesty course within the period from 5 to $6 \mathrm{pm}$ ?

2. What was her deviation from the intended route to the actual route?

3. What were the positions of the Entrance "BA" buoy and "AR" buoy?

4. Was she proceeding along Boston Traffic Lanes at $5 \mathrm{pm}$ ?

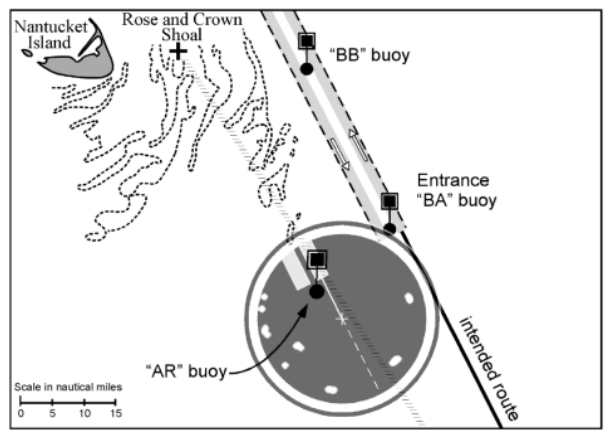

2. Study 'Case Study 1' by the slides of Presentation "Overreliance on Navigational Aids".

Coming from the radar screens of the Royal Majesty passing through/along Boston Traffic Lanes comment on compass errors and navigational mistakes of Watch Officer, which led to the accident. Choose the correct actions in the situation. 


\section{Case Study I - Royal Majesty:}

Radars Radar map is displayed as derived from the GPS data Radar image relies on what the radar scanner sees. Underlying the radar map is the actual radar image Officer failed to:

1. To reduce speed when entering the Precautionary Area of the Traffic Separation Scheme;

2. Taking into account radar range scale, he failed to proceed in the designated traffic lane;

3. To take a relative bearing on the Entrance "BA" buoy;

4. To navigate safely, with particular alertness and caution.

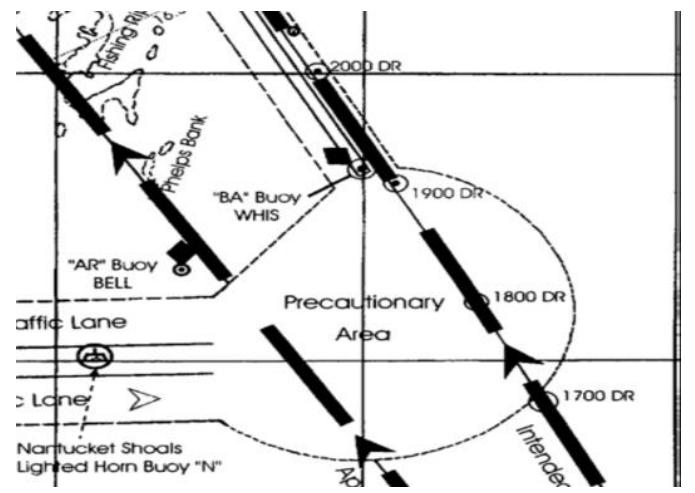

3. Listen to the supplementary information on the topic and describe your actions in the situation.

....Coastguard Navigational Warning NR...

15. POSITION LAT $36^{\circ} 55^{\prime} \mathrm{N}$ LONG $075^{\circ} 55^{\prime} \mathrm{W}$ LIGHT-and-WHISTLE BUOY HAS BEEN REPLACED BY PILLAR LIGHT - and - WHISTLE BUOY PAINTED RED and EXHIBITING Fl(2)R

16. LIGHTBUOY No. $1036^{\circ} 53^{\prime} \mathrm{N} 075^{\circ} 58^{\prime} \mathrm{W}$ UNLIT

17. LIGHTBUOY No.5 $36^{\circ} 50^{\prime} \mathrm{N} 076^{\circ} 00^{\prime} \mathrm{W}$ OFF STATION

18. S.....................ISLET LIGHT UNRELIABLE

19. LIGHTBUOY ...........NORTH ...........EAST REPORTED SHOWING ISO LIGHT.

Together with Master and OOW .... Read the NAVTEX bulletin to know which buoys are unlit, off station, missing or unreliable and other navigational information. Study Reference Book "Symbols and Abbreviations", pilot-book and chart of the navigational area the vessel is proceeding. 


\section{Linguistic-expressive stage.}

Now, cadets, at this stage you'll be taught not only use the terms on the topic "Passing through Narrows and Canals" but will be familiarized with emphatic/emotional expressions, further to apply them in dialogical and polylogical speech on the topic.

1. Read the colloquial expressions with the translation and write them down into the vocabulary.

\begin{tabular}{|l|l|}
\hline Well done. & Отлично. \\
\hline Very well. & Очень хорошо. \\
\hline I can't recall just now. & Я не могу вспомнить прямо сейчас. \\
\hline Very well. & Очень хорошо. \\
\hline And surely... Sure, sir. / Surely not. & И конечно.../ Конечно, сэр. / Конечно, нет. \\
\hline Now ... / Now, next question ... & Итак.../ Итак, следующий вопрос... \\
\hline I think.... & Я думаю, ... \\
\hline Yes, confirm. / Yes, certainly. & $\begin{array}{l}\text { Да, подтверждаю. / } \\
\text { Да, конечно. }\end{array}$ \\
\hline Here it is. & Вот, пожалуйста. \\
\hline Well, gentlemen ... & Ну, джентльмены ... \\
\hline Firstly, ... / First of all, ... & Во-первых, / Прежде всего, ... \\
\hline $\begin{array}{l}\text { You might guess. / You can easily } \\
\text { guess. }\end{array}$ & $\begin{array}{l}\text { Вы могли бы предположить. / Вы легко } \\
\text { можете предположить. }\end{array}$ \\
\hline By the way, ... & Между прочим, ... \\
\hline Let's begin with ... & Давайте начнем с ... \\
\hline What's wrong? / You are wrong. & Что случилось? / Вы ошиблись. \\
\hline I'll try to do my best. & Я сделаю все возможное. \\
\hline As far as I remember, ... & Насколько я помню, ... \\
\hline Now assume, ... & Сейчас предположи, ... \\
\hline
\end{tabular}

2. Read the micro-dialogues with some of these expressions and roleplay them.

\section{I dialogue:}

Captain: Guys, do you remember my task to revise the ColRegs? Now I want to check your knowledge. I'd like to ask some questions.

Boris Molchanov: I'll try to do my best to answer your questions correctly.

Captain: Let's begin with the following. What is the Rule governing two power-driven vessels crossing so, as to involve a risk of collision?

Boris Molchanov: As far as I remember, the vessel, which has the other on her port side, shall keep out of the way of the other.

Captain: No, you are wrong. I think, you'd better recall Rule 15 of the ColRegs. 


\section{II dialogue:}

Captain: Well, gentlemen, we are approaching a narrow now. What is the Rule governing narrow channels?

Boris Molchanov: Surely, Sir. I can answer. Firstly, this Rule is No.9 of ColRegs "Narrow Channels". Every power-driven vessel shall when safe and practicable keep to that side of the fairway or mid-channel which lies on the starboard side of such vessel.

Captain: That's correct. Well done.

\section{III dialogue:}

Captain: Ok. We'll discuss your answers later. Now assume that you are the Officer on the watch and proceed. On your Portland a crossing vessel whose course appears to be $09^{\circ}$ to your starboard side. Her bearing doesn't appreciably change and she has apparently not altered her course or speed since you first observed her. Is there any appropriate signal which you can sound to indicate to the vessel the presence of your ship?

Boris Molchanov: Yes, I may give at least 5 short and rapid blasts of the whistle as signifying my doubt. The other vessel is taking action to avoid a collision.

Captain: You can easily guess which Rule is that.

Boris Molchanov: I can't recall just now.

\section{Read the set of the situation and develop it with the possible solution.}

\section{I situation set:}

Two hours prior to entering the narrow the OOW of our ship calls VTS (Vessel Traffic Service) at the pilot station and gives them all the required information about the ship. They instruct him to proceed to the pilot station to pick up the Pilot. The ship's crew is getting ready for pilotage.

Possible development of the situation:

Crew Team, including Master, OOW, Second Officer and Pilot cooperate closely, solving step by step their professional tasks for safe navigation, i.e. in the following manner:

OOW: Captain, last fix shows the ship is on track. Course $120^{\circ}$ Speed 17 knots. The steering gear is changed to. Is manual control as planned? I have now changed the fix period to 10 minutes. I have called additional crew for pilot station and anchor station duties. ETA at pilot station is $0200 \mathrm{hrs}$. Do you want me to confirm pilot boarding?

MASTER: Yes, confirm ETA with pilot and ask his preferred boarding speed and which side he wants the lee.

10 minutes later

SECOND OFFICER: Pilot wants us to rig pilot ladder on the portside 3 meters above the water. His preferred boarding speed is 4 knots. 
MASTER: Reduce speed to 4 knots. Rig the pilot ladder on the portside 3 meters above the water. Make a lee on the portside.

Some time later

SECOND OFFICER: The pilot boat is approaching our vessel. Do you want me to go down to meet the pilot?

MASTER: Yes, but take a walkie-talkie with you and keep me informed.

Now pilot enters the bridge. The ship hoists flags " $G$ " and " $H$ "

PILOT: Good morning, Master.

MASTER: Good morning, Pilot.

PILOT: What are the ship's particulars?

MASTER: Her length overall is ..... metres, her breadth is ... metres. Her maneuvering speed is ... knots and

Sea speed is knots. Here is the pilot card.

PILOT: Very well. We will pass a buoy every ten minutes. Have your OOW stand near the telegraph and write down the depth of the channel near each buoy?

MASTER: Now, are there any obstructions in the channel?

PILOT: Yes, there is a wreck half a cable off the axis of the fairway. The water there is 15 feet on it. The wreck is marked by buoys. We'd better leave it on our starboard. By the way buoy No.5 is off station. Have you received the Navtex?

MASTER: Yes, we have.

PILOT: Here dredging is in progress. We should proceed exactly along the leading marks.

MASTER: Any other operations in progress in the channel, pilot?

PILOT: Yes, cable laying operations not far from here. Buoy No.10 is unlit. Please show me where it is on the radar.

MASTER: Here it is.

PILOT: Full ahead. Is the engine ready for maneuvering?

MASTER: Yes, certainly.

PILOT: How many revolutions?

MASTER: 110 .

PILOT: Keep as near to the outer limit of the channel, which lies on your starboard side as possible because there is a strong current here. Starboard 10!

MASTER: Ok, Pilot. Starboard 10!

HELMSMAN: Starboard 10!

Meanwhile the OOW makes the following entry in the log book.

"03.00. Vessel proceeding under pilotage through designated buoyed channel in the narrow by recommended

Track. All necessary safety precautions are taken. Safe speed. Master on the bridge. A.B. ... at the helm". 


\section{II situation set:}

Now assume, you are a stand-on vessel. You might easily guess and then determine exactly that a risk of collision exists with the vessel proceeding in the opposite direction, adjacent traffic lane.

Describe your actions in the situation. What will you do, first of all?

Now, next question may be: "In which way will you try to attract her attention, contact by VHF". What recommendations shall be given to the other, give-way vessel, what's wrong with her actions?

\section{III situation set:}

Your vessel is entering the Dover Strait. The weather conditions deteriorate, the visibility is bad. You are taking over the watch.

Describe what important things are for successful taking over the watch, positive actions for safe navigation in the narrow channel. Sure, you should observe good seamanship and do your best not to impede the passage of the other vessels proceeding in the traffic separation scheme.

V. EL productive stage.

At the $5^{\text {th }}$ stage of learning the professional topic "Passing through Narrows and Canals" we can practice the key terms and collocations in solving professional situations we show you how to transfer the knowledge to role-playing Case Studies on the topic. Do not forget to express your ideas and feelings using the emphatic/emotional expressions.

1. Read the situation and propose the professional solution to avoid such situations in your future professional activity, taking into account the observance of good seamanship.

Near-miss in Suez Canal.

A 106 m tanker was transiting the Suez Canal at about 13.5 knots in the south-west bound lane of the traffic separation scheme and was overtaking a small vessel on her starboard side. Her officer of the watch observed a small general cargo vessel crossing from port to starboard making about 8 knots. Before crossing the traffic lane the cargo vessel informed Suez Coastguard of her intentions.

When the distance between two vessels had closed to 4 miles, the tanker's OOW assessed that a risk of collision existed. The crossing vessel took no action. At a range of about 2 miles, the tanker tried calling on VHF and flashed his Aldis light. There was no response. The range closed further.

As the tanker (the stand-on vessel) was unable to alter her course to starboard because of the close proximity of the vessel being overtaken, she reduced speed and came hard-to-port. 
The tanker passed astern of the crossing vessel at a distance of about 0.8 miles. The crossing vessel took no action throughout the incident.

\section{The lessons and possible solution of the situation.}

Two cadets are discussing the case with OOW.

Andrew: Yes certainly, we can easily guess that every bridge watch keeper has to be familiar with this type of incident, in the narrow channels and canals especially. By the way, Nick, do you know that Dover Strait and Suez Canal are the busiest waterways in the world?

Nick: Yes, of course. I know that transiting through them, in TSS requires a full understanding of ColRegs and the confidence to implement them correctly without embarrassing other vessels' intentions.

$\boldsymbol{O} \boldsymbol{W} \boldsymbol{W}$ : Yes, cadets, I confirm this fact. I assume that the give-way vessel thought he could safely cross in front of our vessel, transiting the south-west bound lane of the TSS. Well, gentlemen, think carefully about how the other man on the other vessel will interpret your actions. You'd better recall ColRegs, Rule 15.

Andrew: As far as I remember, Sir, alteration of course to starboard, and/or slowing down by the give-way vessel is preferable to crossing a vessel ahead, even if alteration required is in excess of 60 degrees.

$\boldsymbol{O O W}$ : Well done, you know that alteration to port by the stand-on vessel should, where possible, be avoided by Rule 17, ColRegs.

Nick: Sure, Sir. We remember also that if possible, it is always better to overtake a vessel on your port side to leave the starboard side clear for alterations.

OOW: By the way, the fact that Coastguard has been informed of the intended action does not relieve a vessel of her obligations under the ColRegs.

2. Read the situation and discuss with the colleagues the way out to avoid the accident "Near Miss in Dover Strait TSS". Answer and dispute the questions on the narrative.

The $6,391^{\circ}$ gt reefer vessel Sarafan was proceeding in the south-west bound lane of the Dover Strait TSS on a course of $227^{\circ}$.

Another reefer vessel, the $4,574^{\circ}$ bgt Polestar, was in the opposite lane and heading northeast, but bound for the pilot station Dover. To achieve this she made her heading $350^{\circ}$ to cross the TSS. It was not an uncommon situation.

Sarafan first detected Polestar at a distance of 6 miles and determined that a risk of collision existed. As the Stand-on vessel in accordance with Rule 17, she maintained her course and speed. She was watching Polestar carefully and expected her to take avoiding action.

By the time, the distance between the vessels had reduced to approximately 1 mile, the bridge team onboard Sarafan had become very 
concerned that the other vessel appeared to be doing nothing to give way. She tried, first, to attract the other vessel's attention by using sound signals in accordance with Rule 34(d), and then by VHF radio, channel 16.

As the distance between the vessels continued to close, Sarafan altered course to port. Polestar, the give-way vessel, eventually reduced speed and then stopped her engines.

The vessels passed each other at a distance of 1 cable. Polestar passed ahead of Sarafan.

\section{Answer the question on the narrative.}

1. How can Dover Strait be characterized in view of shipping?

2. Now, the next question:"What facilitates sailing in congested waters of Dover Strait?"

3. By the way, in what lanes were the reefers sailing?

4. Now assume, was the situation ordinary?

5. Can you easily guess, what vessel was stand-on and in accordance with which Rule?

6. What did bridge team of the stand-on vessel become concerned of?

7. What measures were undertaken by the stand-on vessel "Sarafan" in order to avoid close approach?

8 . What was done by the watch keeper of the give-way vessel?

9. At what distance did the reefers pass each other?

10. What actions should have been undertaken by the give-way vessel according to Rule 15 ?

11. What do common courtesy and good seamanship demand?

12. Which Rule is the shortest? What is it about?

13. What is the most basic of all watch keeping duties?

14. Which altering the course of the "Sarafan" aggravated the situation?

15. What must be learnt from the incidents of close quarter situation?

4. Read the situation and propose your professional solution of the circumstances taking into account good seamanship. After arrival into the nearest port invite Surveyor on board your vessel to estimate the scope of damage to the ship.

\section{Never Mind the Waypoint - Mind the Ship.}

A small coaster was following a route southwest bound in the English Channel. It was dark and the OOW was navigating by GPS, using the crosstrack error function to monitor the ship's position relative to the planned track and to make appropriate course adjustments to reach the next waypoint. He saw an overtaking ship proceeding astern and slightly to starboard. The OOW monitored the other ship's approach, and identified her from the AIS. 
When the overtaking ship was about 7 miles astern the OOW tried to call her by VHF radio. Receiving no response, he switched on the accommodation floodlights to make his ship more visible. There was still no action from the overtaking ship as for her intention and so, in a further attempt he switched on his searchlight and directed it at the other ship. Again he called by VHF, with no response.

With the other ship now fewer than 4 cables astern, the OOW altered course by $10^{\circ}$ to port. However, after 2 or 3 minutes, with both sidelights of the other ship still visible, he altered back to his original course to take his stern away from the overtaking ship's bow.

When the ship was less than a cable away the OOW called by VHF radio, again with no response, and then sounded an appropriate signal-long blast on the ship's whistle. The other ship, which was now about $50 \mathrm{~m}$ on the starboard beam, then altered course to starboard, causing her port quarter to collide with the coaster's starboard side.

The OOW stopped the engines, switched on the deck lights and mustered the crew to check for damage. After Identifying minor damage only, and exchanging relevant information, both ships resumed their respective voyages.

\section{Comment on your actions in such a situation to avoid it to be critical. Possible solution to the situation:}

I think that the overtaking vessel should have taken early and substantial action to keep well clear and the coaster's OOW should have taken effective avoiding action. Surely, the OOW should not use only GPS but refer to a chart to be aware how much safe water there is on either side of the planned track. He should have maintained an overall appraisal of the situation.

The OOW should not only illuminate his own vessel by searchlight but sound also at least five short and rapid blasts on the whistle, supplemented with a light signal.

Let's begin with the fact that identification of another ship by AIS is not enough for collision avoidance, VHF radio call was intended to prevent.

The OOW's actions in altering course to port should have been larger than $10^{\circ}$ to port to be readily apparent to the overtaking ship. As far as I remember, stand-on vessel MUST take action when collision cannot be avoided by the action of the give-way ship alone.

Now you can create the dialogue with the Surveyor you have invited on board to estimate the scope of damage to your vessel, drawing up Statement of Facts, Sea Protest and lodging them to the Notary Public and Port Authorities. Get ready to protect the ship's interests and the interests of the parties concerned. 
VI. EL reflexive stage.

At the $6^{\text {th }}$ stage we propose you, cadets, to find your own solutions to the complicated professional tasks, at this stage besides professional terms and collocations you have already studied and emotional expressions we add some new terms. You should study them yourself, in case of difficulty, find the translation below.

1. Make the analysis of navigation accidents for the last 5 years in 7 top Platforms dedicated to Shipping Industry (like MARs, MAIB, the Danish Maritime Accident Investigation Board, etc.) and specify the number of cases which happened in the narrow channels or fairways due to discommunication in maritime English or other reasons. Now we produce the extracts of cadet's research work according to the task.

Case 1: A vessel was transiting Suez Canal with pilot onboard where she was supposed to be navigating along the fairway of the channel, however as she drifted away from the centre line the pilots and bridge team used corrective helm and engines to counter it...

The vessel had picked up speed again and resumed the canal transit. The senior officer on watch neither called master nor discussed it later on with $\operatorname{him...}$

The vessel crossed the canal and while she was loading in load port a large thud was heard again and the officer on watch noticed water rushing in ballast tank No. 1, 2, 3 on Port Side. Due to continual stresses on a damaged, deformed and fatigued hull the weak zone crumbled and gave away...

Now cadets, coming from the information you have found and analyzed from 10 top platforms, the acquired experience get ready two projects, in two teams.

First team (I) should safely proceed on passenger cruise ship entering the Bosporus from the Black Sea.

Your task is to contact with Traffic Control Centre, inform them your initial data, Route Plan, agree upon traffic separation lane to proceed, maintain your course and speed during passage, not to impede passage of the other vessels, observe the compliance with ColRegs.

Initial data:

Ship's type: Passenger Cruise Ship,

Displacement: $24841 \mathrm{t}$.

Length: $230.9 \mathrm{~m}$.

Width: $27.8 \mathrm{~m}$.

Draught: $8.0 \mathrm{~m}$. 
Route Plan:

1. Lat 04117.9N, Long 029 08E, Course 270.7, Speed (knt) 24.0, Dist (nm) 1.38 , ETA 0.03. Etc.

Second team (II) should safely navigate on oil tanker entering the Bosporus from the Black Sea.

You proceed in restricted visibility, steer for the starboard side buoys, contact with VTS as for intentions of the other passing vessels, contact with pilot during pilotage, reduce your speed as per Rule 19, ColRegs, keep an eye on the oncoming vessels.

Initial data:

Type of ship: Oil Tanker,

Displacement: $77100 \mathrm{t}$.

Length: $242.8 \mathrm{~m}$.

Width: $33.2 \mathrm{~m}$.

Draught: $12.5 \mathrm{~m}$.

Route Plan:

1. Course 206, Bearing 298, Distance 0.3, ETA 12.13. Etc.

\section{SUMMARY}

This article is devoted to the attempts of the author to combine methodological, some psychological, linguistic and to some extent technological constituents of "face-to-face" and distant learning mode in teaching Maritime English to future and functioning seafarers in the world. The research contains hypothesis as for linguistic modeling of ME teaching process to the cadets/students, non-native speakers. The intermediary conclusions of the author are based on the scientists' researches and her own experience in teaching ME to the cadets in Odessa Maritime Academy, its affiliations in Ukraine and abroad, Shanghai University. We've tried to approach our issues getting ready the teaching material for Unified Communication Platform (UCP) coming from the event-argument structures in static meta-system to dynamic linguistic/developing system. The principles of integrated teaching process are aimed at arranging learner's image in foreign language thinking as psychological "chain of multitude rows of objects" expressed at linguistic modeling stages. They are linguisticconceptual, EL receptive, EL reproductive, linguistic-expressive, EL productive, EL reflexive. We conducted some experimental on-line teaching $\mathrm{ME}$ and analyzed the results which are intermediary also. We acted within rhema-thematic field of our cadets' future professional activity, creating thematic domain as a link of three main positions: "concept"-"frame""discourses". 


\section{REFERENCES}

1. Keegan D. Foundations of distance education ( $3^{\text {rd }}$ edition). London : Routledge. 1996. P. 21.

2. Клепко С.Ф. Інтеграція і поліморфізм знання у вищій освіті. Філософія освіти. 2005. № 2. С. 20, 32.

3. Берталанфи К.Л. Теория систем и системный анализ : учебное пособие для дистанционного обучения. Москва : Прогресс. 1969. С. 57. URL: http://fpi-kubagro.ru/teoriasistem-i-sistemnyj analiz.

4. Садовский В.Н. Системный анализ. Новая философская эничиклопедия : в 4 т. Т. III. С. 35-71.

5. Уёмов А.И. Системные аспекты философского знания. Одесса : Негоциант, 2000. 160 c. URL: http://philosof.onu.edu.ua/elb/uemov/ uemov.pdf.

6. Эволюционная эпистемология и логика социальных наук: Карл Поппер и его критики / составление Д.Г. Лахути, В.Н. Садовского и В.К. Финна ; перевод с английского Д.Г. Лахути ; вступительная статья и общая редакция В.Н. Садовского ; послесловие В.К. Финна. Москва : Эдиториал УРCC, 2000. 464 с. URL: http://www.pseudology.org/psyhology/EvolutionEpistemology2.pdf.

7. Chomsky N. Three Factors in Language Design. Unpublished manuscript. 2007. P. 30.

8. Scrivener J. Learning Teaching: The Essential Guide to English Language Teaching. $3^{\text {rd }}$ edition. MacMillan. 2011.

9. Уёмов А.И. Системный подход и общая теория систем. Москва : Мысль, 1978. 272 с. URL: http://www.philosof.onu.edu.ua/elb/uemov/ system_general_theory.pdf.

10. Anohin P.K. In Bol'shaya Rossijskaja Jenciklopedia. Vol. 2. M., 2005. P. 18.

11.Берталанфи К.Л. Теория систем и системный анализ : учебное пособие для дистанционного обучения. Москва : Прогресс, 1969. С. 57. URL: http://fpi-kubagro.ru/teoriasistem-i-sistemnyj analiz.

12. Lueddeke G.R. (2003) Professionalising teaching practice in higher education: a study of disciplinary variation and "teaching-scholarship". Studies in Higher Education, 28(2). P. 213-228.

13. Пассов Е.И., Кузовлева Н.Е. Основы коммуникативной теории и технологии иноязычного образования. Москва : Русский язык. Курсы, 2010. C. 62-66. URL: osnovy_kommunikativnoi_teorii.pdf.

14. Chen H.C.; Leung Y.S. (1989) Patterns of Lexical processing in a nonnative language. Journal of Experiment Psychology: Learning, memory and Cognition, 12. P. 397-401.

15. Monaghan P.; Chang Ya-Ning, Welbourne S.; Brysbaert M. Exploring the relations between word frequency, language exposure and 
bilingualism in a computational model of reading. April 2017. Journal of Memory and Language 93. P. 3, 10.

16. Alexander F.K. The Changing Face of Accountability: Monitoring and Assessing Institutional Performance in Higher Education. July 2000. The Journal of Higher Education 71 (4). P. 411-431.

17. Arshad K.; Imran M.A. Increasing the interaction time in a lecture by integrating flipped classroom and just-in-time teaching concepts. June 2013. Compass Journal of Learning and Teaching 4 (7). P. 1-18. URL: https://journals.gre.ac.uk/index.php/compass/article/view/84.

18. Deem R.; Mok K.H.; Lucas L. Transforming Higher Education in Whose Image? Exploring the Concept of the 'Word-Class' University in Europe and Asia. March 2008. Higher Education Policy 21 (1). № 83-97. URL: http://citeseerx.ist.psu.edu/viewdoc/download?doi=10.1.1.456.5712 $\&$ rep=rep $1 \&$ type $=$ pdf.

19. Keegan D. Foundations of distance education ( $3^{\text {rd }}$ edition). London : Routledge, 1996. P. 21.

20. Scuratov A.K. (2003) Methodological researches in the context of distant learning. Saint Petersburg, 2003. № 3. P. 24-30.

21.Zhang D.; Zhao J.L.; Zhou L.; Nunamaker Jr., J.F. Can E-learning Replace Classroom Learning? May 2004. Communications of the ACM 47 (5). P. 75-79. URL: https://userpages.umbc.edu/ zhangd/Papers/ CACM1.pdf.

22. Попова З.Д., Стернин И.А. Когнитивная лингвистика. Москва : АСТ: Восток-Запад, 2007. С. 8-12.

23. Чейф Ч.Л. Память и вербализация прошлого опыта. Hовое в зарубежной лингвистике. Вып. ХІІ. Москва, 1983. С. 35, 73.

24. Филлюр Ч. Фреймы и семантика понимания речевых актов. НЗЛ. Вып. ХХІІІ. Москва, 1988. С. 52-90.

25. Дейк ван Т.А. Фреймы знаний и понимание речевых актов. Язык. Познание. Коммуникация. Москва : Прогресс, 1989. С. 12, 40.

26. Van Djik, T. Social cognition and discourse. H. Giles and R. $R$. Robinson (eds) Handbook of Social Psychology and Language. Chichester : Wiley. 1989. P. 164-165.

27. Minsky M. The Emotion Machine. Simon and Schuster. November 2006. P. 1, 25.

28. Morris D. (1967) The Naked Ape: A Zoologist's Study of the Human Animal Jonathan Cape Publishing. 1967. P. 6. URL: https://folk.ntnu.no/krill/bioko-references/Morris\%201967.pdf.

29. Stones E. (1968) Verbal labeling and concept formation in primary learning and teaching programmed introduction. New York, 1968. P. 11.

30. Мартынова Р.Ю. Моделирование звеньев организационного и содержательного блоков процесса обучения образовательным 
дисциплинам. Наука $i$ освіта. 2020. № 3. С. 155-163. URL: https://scienceandeducation.pdpu.edu.ua/doc/2020/3_2020/22.pdf.

31. Diesel H. Linguistic nativism. 2015. P. 14. URL: http://www.personal.unijena.de/x4diho/LA_Linguistic_nativism.pdf.

32. Kerr B. (2007, February 3) MS 4.7 Re: What Connectivism is. Online Connectivism Conference: University of Manitoba. P. 17. URL: http://ltc.umanitoba.ca/moodle/mod/forum/discuss.php?d=12.

33. Kop R.; Hill A. Connectivism: Learning Theory of the Future or Vestige of the Past? October 2008. International Review of Research in Open and Distance Learning 9(3). P. 7, 10. URL: https://www.researchgate.net/publication/26544860_Connectivism_Learning _Theory_of_the_Future_or_Vestige_of_the_Past.

\section{Information about the author:} Ivasiuk N. A., Candidate of Pedagogical Sciences, Associate Professor, Professor at the English Language Department National University "Odesa Maritime Academy" 8, Didrihsona str., Odesa, 65029, Ukraine 